\title{
The effect of pituitary adenylate cyclase-activating polypeptide on elevated plus maze behavior and hypothermia induced by morphine withdrawal
}

\author{
Nándor Lipták ${ }^{\mathrm{a}}$, Roberta Dochnal ${ }^{\mathrm{c}}$, Anikó Babits ${ }^{\mathrm{a}}$, Krisztina Csabafi ${ }^{\mathrm{a}}$, Júlia Szakács ${ }^{\mathrm{a}}$, Gábor Tóth ${ }^{\mathrm{b}}$, \\ Gyula Szabó ${ }^{\mathrm{a}, *}$
}

a Department of Pathophysiology, Faculty of Medicine, University of Szeged, Szeged, Hungary

${ }^{\mathrm{b}}$ Department of Medical Chemistry, Faculty of Medicine, University of Szeged, Szeged, Hungary

${ }^{\mathrm{c}}$ Department of Child and Adolescent Psychiatry, Faculty of Medicine, University of Szeged, Szeged, Hungary

\section{A R T I C L E I N F O}

\section{Article history:}

Received 28 April 2011

Accepted 12 December 2011

Available online 9 January 2012

\section{Keywords:}

PACAP

Morphine withdrawal

Anxiolytic-like behavior

Elevated plus maze

Mice

Hypothermia

\begin{abstract}
A B S T R A C T
The aim of the present investigation was to study the effects of pituitary adenylate cyclase-activating polypeptide (PACAP) on morphine withdrawal-induced behavioral changes and hypothermia in male CFLP mice. Elevated plus maze (EPM) and jump tests were used to assess naloxone-precipitated morphine withdrawal-induced behavior responses. Different doses of subcutaneous (s.c.) naloxone, (0.1 and $0.2 \mathrm{mg} / \mathrm{kg}$, respectively) were used to precipitate the emotional and psychical aspects of withdrawal on EPM and $1 \mathrm{mg} / \mathrm{kg}$ (s.c.) was used to induce the somatic withdrawal signs such as jumping, and the changes in body temperature. In our EPM studies, naloxone proved to be anxiolytic in mice treated with morphine. Chronic intracerebroventricular (i.c.v.) administration of PACAP alone had no significant effect on withdrawal-induced anxiolysis and total activity at doses of $500 \mathrm{ng}$ and $1 \mu \mathrm{g}$. At dose of $500 \mathrm{ng}$, however, PACAP significantly counteracted the reduced motor activity in the EPM test in mice treated with morphine and diminished the hypothermia and shortened jump latency induced by naloxone in mice treated with morphine.

These findings indicate that anxiolytic-like behavior may be mediated via a PACAP-involved pathway and PACAP may play an important role in chronic morphine withdrawal-induced hypothermia as well.
\end{abstract}

(c) 2011 Elsevier Ltd. All rights reserved.

\section{Introduction}

Pituitary adenylate cyclase-activating polypeptide (PACAP) was originally isolated from ovine hypothalamus by its potent activity in stimulating cAMP production in rat anterior pituitary cells (Arimura, 1992). PACAP is a neuropeptide and member of a vasoactive intestinal polypeptide (VIP) superfamily that includes several peptides (VIP, secretin, helodermin, glucagon, peptide histidin isoleucine, galanin, etc.) (Christophe, 1993; Gourlet et al., 1998). The peptide has two amidated forms: PACAP-38 and PACAP-27 (Miyata et al., 1990). The presence of PACAP has been detected in hypothalamus, medial and ventral areas of the diencephalon, central thalamic nuclei, amygdala, bed nucleus of stria terminalis, septum, hippocampus, cingulate and entorhinal cortex, substantia nigra, nucleus accumbens, globus pallidus and sacral spinal cord (Dietl et al., 1990; Joo et al., 2004). Two receptor classes have been described for PACAP in mammalian tissues: type I and type II. Type

\footnotetext{
* Corresponding author. Address: Department of Pathophysiology, Faculty of Medicine, University of Szeged, Semmelweis u. 1, Pf. 427, H-6701 Szeged, Hungary. Tel.: +36 62545 994; fax: +36 62545710 .

E-mail address: szabo.gyula@med.u-szeged.hu (G. Szabó).
}

II was further divided into three subclasses: PAC1, VPAC1 and VPAC2. PAC1 receptors are more selective for PACAP than VIP, but VPAC1 and VPAC2 receptors show similar affinity for PACAP-27, PACAP-38 and VIP (Cauvin et al., 1990; Gourlet et al., 1996). Type I receptors stimulate both adenylate cyclase and phospholipase $C$, thus being coupled to dual transduction pathways, involving interactions with $G$ proteins of both Gs- and Gq-type. PACAP-38 and PACAP-27 were also effective in increasing cAMP release, cellular cAMP content, and total cAMP production in a dose-dependent manner in common carp pituitary cells (Xiao et al., 2002) and in rat neuroepithelial cells (Zhou et al., 2001).

Other behavioral studies examined the PACAP effect on motor stimulation and conditioned place preference (CPP) induced by morphine (Marquez et al., 2009); analgesic tolerance to morphine (Mácsai et al., 2002); mechanical hyperalgesia and thermal allodynia (Sándor et al., 2010). Our earlier experiments demonstrated that PACAP diminished the antinociceptive effect of acute morphine and enhanced the analgesic tolerance to morphine (Mácsai et al., 2002). In a recent report, acute PACAP administration increased the amount of time that animals spent in the open arm/total time rate in morphine treated mice compared to morphine treated mice in the absence of PACAP in the EPM (Szakács 
et al., 2010). Low doses of PACAP (0.03 and $0.3 \mu \mathrm{g})$, which had no effect on basal motor activity, enhanced morphine-induced (5 mg/kg, s.c.) motor stimulation and PACAP-deficient mice exhibited reduced morphine-induced motor stimulation (Marquez et al., 2009). Morphine-induced CPP following a single alternate-day saline/morphine $(10 \mathrm{mg} / \mathrm{kg}$, s.c.) conditioning was blunted in PACAP-deficient mice compared to their wild type littermates (Marquez et al., 2009). In spite of intense research, the mechanisms of PACAP action on morphine withdrawal-induced behavior responses and motor activity changes have not been clarified yet. The goal of the present study was to examine the effects of PACAP on naloxone precipitated morphine withdrawal in two experimental paradigms.

\section{Materials and methods}

\subsection{Animals}

Male CFLP white mice ( $30 \pm 5 \mathrm{~g}$ of weight) of an outbred strain (Domaszék, Hungary) were used. They were kept under a standard light-dark cycle (lights on between 07.00 and $19.00 \mathrm{~h}$ ) with food and water available ad libitum. The animals were kept and treated according to the rules of the Ethical Committee for the Protection of Animals in Research (Faculty of Medicine, University of Szeged, Hungary).

\subsection{Surgery}

For intracerebroventricular (i.c.v.) cannulation, the mice were anesthetized with intraperitoneal (i.p.) injection of sodium pentobarbital (Nembutal ${ }^{\circledR}$, Phylaxia-Sanofi, Budapest, Hungary; $50 \mathrm{mg} /$ $\mathrm{kg}$ ), and a polyethylene cannula was inserted into the right lateral cerebral ventricle and cemented to the skull with cyanoacrylatecontaining instant glue. The experiments were started 4 days after i.c.v. cannulation. Upon conclusion of the experiments, $10 \mu \mathrm{l}$ of methylene blue were injected into the cerebral ventricle of the decapitated animals and the position of the cannula was inspected visually. After injection methylene blue spread throughout the ventricular space was used to verify that the whole amount of PACAP got into the ventricle. Mice with improper cannula placement were excluded from the statistical analysis.

\subsection{Drugs}

For i.c.v. treatments PACAP-38 (synthesized by Gábor Tóth using solid-phase peptide synthesis) were dissolved in artificial cerebrospinal fluid (aCSF) and injected in a volume of $2 \mu \mathrm{l}$. For testing the morphine effects and the somatic signs of withdrawal, morphine- $\mathrm{HCl}$ (Sigma-Aldrich) and naloxone-HCl (Sigma-Aldrich) were used. Control mice received saline s.c. and aCSF i.c.v.

\subsection{Assessment of naloxone-precipitated withdrawal jumping in mice treated with graded doses of morphine}

Precipitated withdrawal jump latency was measured in mice treated with morphine in the presence and absence of PACAP after naloxone ( $1 \mathrm{mg} / \mathrm{kg}$, s.c.) administration. Immediately after the naloxone or saline injection, mice were placed on a circular platform. The precipitated abstinence syndrome was measured by scoring the latency to the appearance of stereotyped jumping from a circular platform $35 \mathrm{~cm}$ in diameter and $70 \mathrm{~cm}$ high (Azarov et al., 1992). A cutoff time of $15 \mathrm{~min}$ was used. The rectal body temperatures and body weights of all animals were also measured 15 , 30,60 min after naloxone injection, and changes in both parameters were calculated.

\subsubsection{Influence of PACAP on naloxone-precipitated morphine withdrawal symptoms}

We used twice daily injections of graded doses of morphine (09.00 and $19.00 \mathrm{~h}$.) as follows: day $1: 20 \mathrm{mg} / \mathrm{kg}$, day $2: 40 \mathrm{mg} / \mathrm{kg}$, day 3: $60 \mathrm{mg} / \mathrm{kg}$, day 4: $80 \mathrm{mg} / \mathrm{kg}$ or saline (Contet et al., 2008). Mice were also treated once a day $(09.30 \mathrm{~h})$ with either PACAP (500 ng/2 $\mu \mathrm{l}$ ) or aCSF i.c.v. On the test day (day 5) animals received in the morning a single morphine injection $(100 \mathrm{mg} / \mathrm{kg}$ s.c., $9.00 \mathrm{~h}$ ) or saline (s.c.). Ninety minutes later aCSF or PACAP was given (10.30 h, i.c.v.). Withdrawal signs were evoked by naloxone administration $(1 \mathrm{mg} / \mathrm{kg}$, s.c.) $2 \mathrm{~h}$ after the final morphine treatment.

Precipitated morphine withdrawal syndrome was induced by $1 \mathrm{mg} / \mathrm{kg}$ naloxone-HCl as described by Azarov et al. (1992)). For treatment of specific groups please see legends to figures (Figs. 1 and 2 ) and Table 1.

\subsection{Elevated plus maze (EPM)}

The elevated plus maze (EPM) is an accepted model for examining anxiety-like behavior in mice (Lister, 1987). Conditions that decrease time spent in the open arms are associated with anxiety-like behavior, whereas increased time spent in the open arms is associated with an anxiolytic effect. The EPM apparatus consists of four arms (87-mm wide, $155-\mathrm{mm}$ long) elevated $63.8 \mathrm{~cm}$ above the ground, with two arms enclosed by $16.3-\mathrm{cm}$-high opaque walls and illuminated with $60 \mathrm{~W}$ light situated $1 \mathrm{~m}$ above the maze. The combination of height, luminosity and open space is assumed to induce anxiety-like behavior in the animal. Behavioral testing was conducted between 11.00 and $13.00 \mathrm{~h}$. Mice were carried to the experimental room in their home cages and habituated to the laboratory for at least $30 \mathrm{~min}$ before testing. Only one EPM apparatus per testing room was present. The apparatus was thoroughly cleaned between mice. Mice were placed in the center of the maze facing toward an enclosed arm and there behavioral activity were recorded for $10 \mathrm{~min}$ (Schulteis et al., 1998). These behavioral parameters were monitored: duration of time spent in the open arms which was defined as all four legs having crossed the entrance line to one of the open arms and total activity which was defined as the total number of crosses between any two arms.

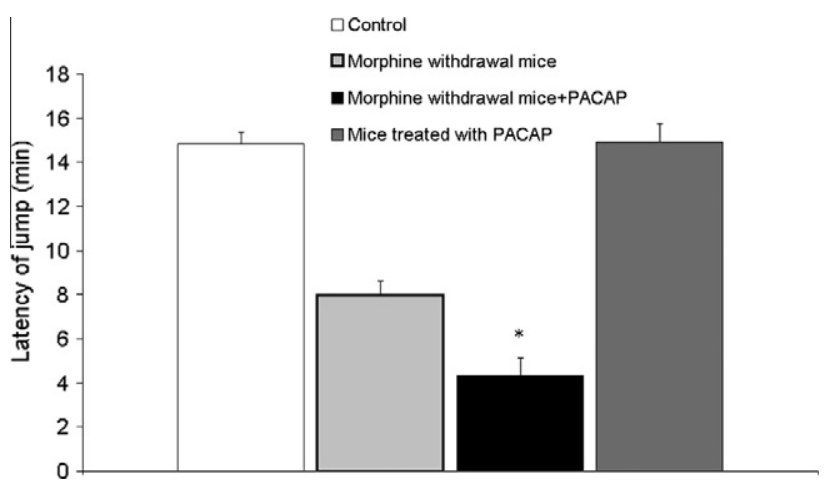

Fig. 1. Assessment of naloxone-precipitated withdrawal jumping in mice treated with graded doses of morphine. Graded doses of morphine $(\mathrm{mg} / \mathrm{kg}$, s.c. per injection) or saline were given twice daily for 5 days (day 1, 20; day 2, 40; day 3, 60; day 4,80$)$. Mice were also treated once a day with either PACAP $(500 \mathrm{ng} / 2 \mu \mathrm{l})$ or aCSF i.c.v. $30 \mathrm{~min}$ after morphine injection. On day 5, $30 \mathrm{~min}$ prior to test either PACAP or aCSF was injected. Naloxone $(1 \mathrm{mg} / \mathrm{kg}$, s.c.) or saline was administered $2 \mathrm{~h}$ after the final injection of morphine at a dose of $100 \mathrm{mg} / \mathrm{kg}$, and the jump latency was immediately measured. Therefore, we injected morphine or saline $2 \mathrm{~h}$; PACAP or aCSF $30 \mathrm{~min}$; naloxone or saline 0 min prior to jumping behavior. Number of mice: control: 9 , morphine withdrawal mice: 10 , morphine withdrawal mice + PACAP: 9, mice treated with PACAP: 9. Bars represent the latency of jump, vertical lines on the top of the bars denote S.E.M., ${ }^{*} p<0.05$ vs. mice given morphine and naloxone. 


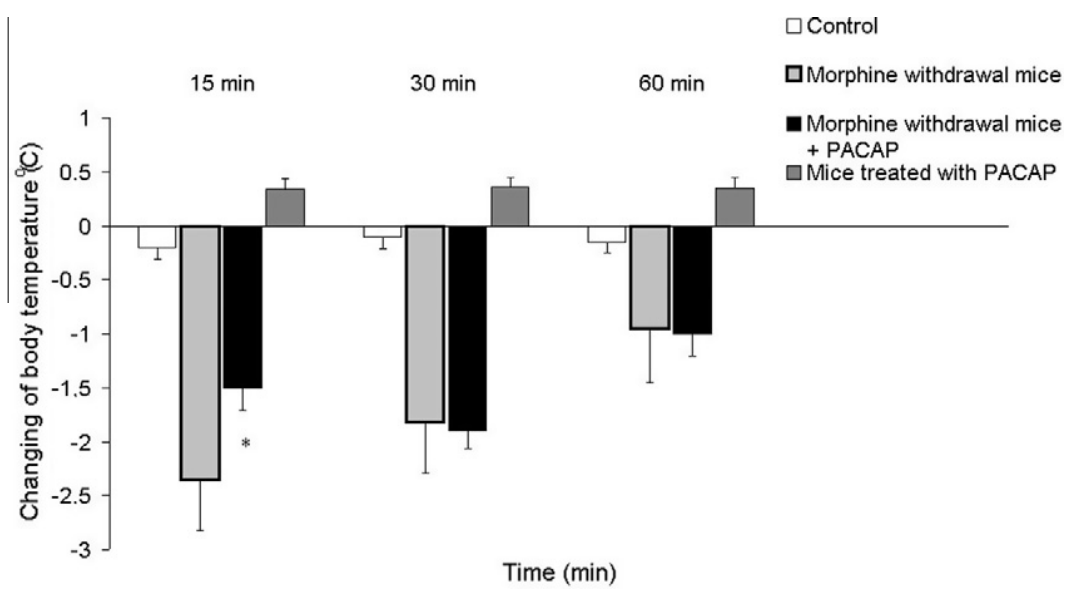

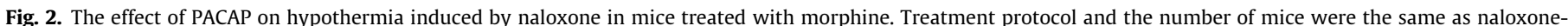

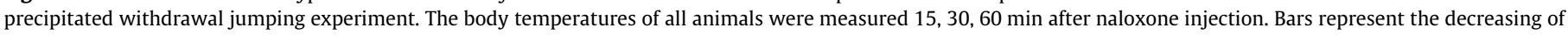
body temperature, vertical lines on the top of the bars denote S.E.M., ${ }^{*} p<0.05$ vs. mice given morphine and naloxone.

\subsubsection{The effects of PACAP on EPM behavior}

Mice were treated once a day $(09.30 \mathrm{~h})$ with either PACAP (500 ng or $1 \mu$ g i.c.v.) or aCSF for 3 consecutive days. On the test day (day 4) PACAP or aCSF was administered 30 min before EPM assessment. The parameters were monitored as mentioned above.

\subsubsection{The effect of naloxone on EPM behavior in mice treated with morphine in the absence of PACAP}

We used twice daily injections of graded doses of morphine (09.00 and $17.00 \mathrm{~h}$.) as follows: day $1: 10 \mathrm{mg} / \mathrm{kg}$, day $2: 20 \mathrm{mg} /$ $\mathrm{kg}$, day 3: $40 \mathrm{mg} / \mathrm{kg}$ or saline (Hodgson et al., 2008).

On the test day (day 4 ) animals received a single dose of morphine $(20 \mathrm{mg} / \mathrm{kg}$, s.c.) or saline (s.c.) in the morning at $09.00 \mathrm{~h}$. Naloxone treatment in a dose of $0.1 \mathrm{mg} / \mathrm{kg}$, or $0.2 \mathrm{mg} / \mathrm{kg}$, s.c. preceded behavioral assessment by $5 \mathrm{~min}$. The behavioral changes were measured $2 \mathrm{~h}$ after the final morphine treatment with EPM test (Higgins and Sellers, 1994; Schulteis et al., 1994). The treatment of specific groups is described below Fig. 3 and on Table 2 .

2.5.2.1. The effect of naloxone on EPM behavior in mice treated with morphine in the presence of PACAP. A previous study carried out in our laboratory used once daily i.c.v. injection of PACAP (Mácsai et al., 2002). Repeated administration of PACAP (500 ng/2 $\mu \mathrm{l})$ significantly increased the chronic tolerance to morphine and enhanced the naloxone-precipitated withdrawal jumping. The aim of that experiment model was to examine the somatic signs of morphine tolerance and withdrawal after naloxone administration. There is another study which described increased EPM open-arm time in mice during naloxone-precipitated morphine withdrawal (Hodgson et al., 2008). We combined these two protocols to examine the effect of PACAP on EPM behavior during naloxone-precipitated morphine withdrawal.

Morphine administration regimen was the same as in the previous experiment. In addition, mice were treated once a day with either PACAP $(500 \mathrm{ng} / 2 \mu \mathrm{l})$ or aCSF (i.c.v.) at $09.30 \mathrm{~h}$. On the test day (day 4) animals received the final morphine dose $(20 \mathrm{mg} / \mathrm{kg}$ s.c.), or saline (s.c.).

$9.00 \mathrm{~h}$ and either aCSF or PACAP (i.c.v.) was given at $10.30 \mathrm{~h}$. Naloxone treatment and behavioral assessment were conducted in the same way as outlined in the previous experiment with one exception that only the higher dose of naloxone was used $(0.2 \mathrm{mg} / \mathrm{kg}$, s.c.). For specific treatment groups and protocols please see the legend to Figs. 4 and 5 and on Table 3.

\subsection{Statistical analysis}

Statistical analysis of the data was made by one-way repeated measure analysis of variance (ANOVA). For significant ANOVA values, groups were compared by Tukey's test for multiple comparisons with unequal cell size. A probability value, $P<0.05$ was considered statistically significant.

\section{Results}

3.1. Assessment of naloxone-precipitated withdrawal jumping in mice treated with graded doses of morphine

Repeated treatment of PACAP shortened jump latency in mice treated with morphine and challenged with naloxone $\left[F_{(3,37)}=\right.$ 23.73, $P<0.023$ ] (Fig. 1).

3.2. The effect of PACAP on hypothermia induced by naloxone in mice treated with morphine

Fifteen minutes after naloxone treatment PACAP blunted hypothermia induced by morphine withdrawal $\left[F_{(3,37)}=32.97\right.$, $P<0.034$ ]. However, 30 and $60 \mathrm{~min}$ after withdrawal PACAP had no significant effect on body temperature (Fig. 2). PACAP treatment alone did not influence the body weight of mice upon withdrawal (data not shown).

\subsection{The effects of PACAP on EPM behavior}

Both doses of PACAP increased the open arm time/total time rate, but no significant difference was observed. There was a slight increase upon the higher dose of PACAP compared to control mice $\left[F_{(2,27)}=3.63, P<0.0614\right]$. PACAP had no effect on total activity (data not shown).

\subsection{The effect of naloxone on EPM behavior in mice treated with} morphine in the presence or absence of PACAP

Naloxone $(0.2 \mathrm{mg} / \mathrm{kg}$, s.c. $)$ administration in mice treated with morphine significantly increased the open-arm time/total time rate compared to the control mice and mice treated with morphine $\left[F_{(3,42)}=3.97, P<0.0146\right]$. Naloxone also significantly enhanced the number of open arm entries/total entries rate compared to 


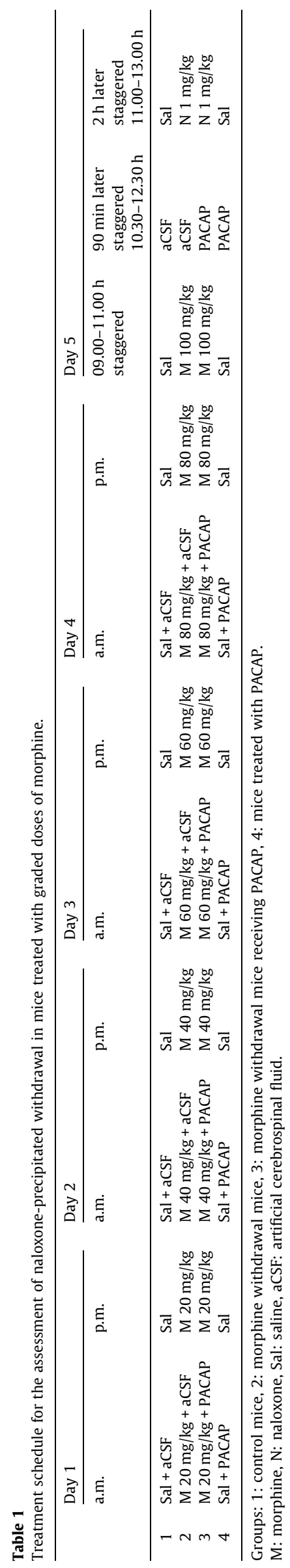

the control mice and mice receiving $0.1 \mathrm{mg} / \mathrm{kg}$ naloxone $\left[F_{(3,42)}=4.18, P<0.0117\right]$. Naloxone $(0.1 \mathrm{mg} / \mathrm{kg}$, s.c. $)$ had no significant effect on withdrawal behavior compared to the mice treated with morphine (Fig. 3).

In combination with PACAP (for treatment details see Table 3), naloxone administration in mice treated with morphine again significantly increased the open-arm time/total time rate compared to the control mice and mice treated with morphine $\left[F_{(3,35)}=5.32\right.$, $P<0.0037]$. However, PACAP had no significant effect on EPM compared to morphine withdrawal group (Fig. 4).

\subsection{The effects of PACAP on motor activity in controls and mice treated with morphine challenged with naloxone}

Total motor activity was reduced in mice treated with morphine, a response that was not altered in mice treated with naloxone. However, PACAP treatment blocked the reduction of total activity induced by chronic morphine treatment $\left[F_{(3,35)}=5.80\right.$, $P<0.0026$ ] (Fig. 5).

\section{Discussion}

In this study we investigated the effect of PACAP on morphine withdrawal-induced behavioral changes and hypothermia in mice. A previous experiment demonstrated that PACAP (500 ng, i.c.v.) significantly diminished the analgesic effect of acute morphine in mice (Mácsai et al., 2002). Morphine indirectly decreases the intracellular level of cAMP due to inhibition of the enzyme adenylate cyclase (Beitner et al., 1989; Kuriyama et al., 1978), but PACAP increases the activity of adenylate cyclase, thus increasing the intracellular level of cAMP (Absood et al., 1992). In contrast to the acute morphine treatment, withdrawal from chronic morphine significantly upregulates the mRNA level of adenylate cyclase in the nucleus raphe magnus, which causes an increase in cAMP level and hyperalgesia (Bie et al., 2005).

PACAP alone caused hyperthermia in a dose dependent manner in rat (Pataki et al., 2000) with 1000 ng induced the largest elevation in body temperature. The hyperthermic effect of PACAP may be mediated via a cyclooxygenase-involved pathway, and it suggest that PACAP may play an important role in thermoregulation (Pataki et al., 2003). Morphine was able to induce both hyperthermia (through $\delta$ - and $\kappa$-opioid receptors) or hypothermia (through $\mu$-opioid receptors) depending on the dose administrated, but naloxone-precipitated morphine withdrawal evoked hypothermia (Wang et al., 2008). In our study, we found that naloxone induced hypothermia in mice treated with morphine was decreased by PACAP (Fig. 2).

Chronic morphine withdrawal is known to be anxiogenic in humans and, using the EPM, was proved to be anxiogenic in rats as well (Schulteis et al., 1998; Zhang and Schulteis, 2008). In contrast to rats, both naloxone-precipitated (Hodgson et al., 2008), and spontaneous opioid withdrawal (Buckman et al., 2009) exhibited reduced anxiety-like behaviors on EPM in mice. In contrast to EPM results, naloxone-precipitated morphine withdrawal caused a rise in plasma and brain corticosterone levels (Budziszewska et al., 1996; Hodgson et al., 2008; Kishioka et al., 1994; Rabbani et al., 2009). Different doses of naloxone $(0.1 ; 0.2 \mathrm{mg} / \mathrm{kg})$ increased EPM open-arm time during naloxone-precipitated morphine withdrawal compared to control and mice treated with morphine (Hodgson et al., 2008).

For EPM experiments, we respected the protocol of Hodgson et al. (2008). Our aim was not to induce somatic signs of withdrawal on the EPM experiments. Naloxone $(0.2 \mathrm{mg} / \mathrm{kg}$, s.c. $)$ administration in mice treated with morphine significantly increased the open-arm time/total time rate compared to the control mice and 


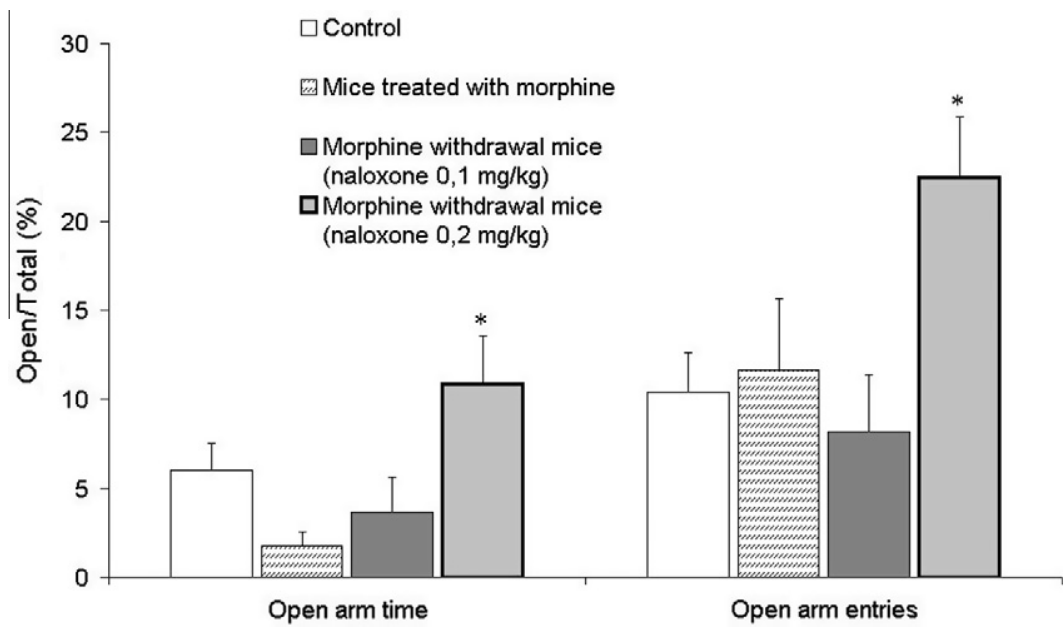

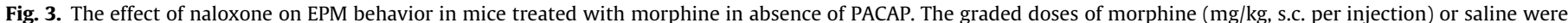

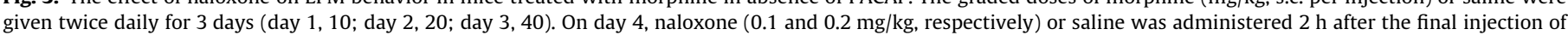

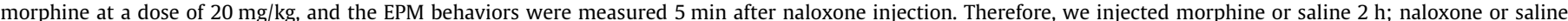

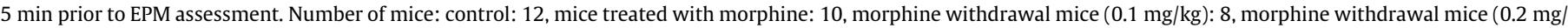

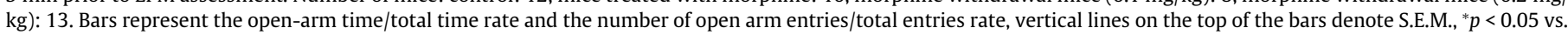
control mice and mice treated with morphine.

Table 2

Treatment schedule to investigate the effect of naloxone on EPM behavior in mice treated with morphine in the absence of PACAP.

\begin{tabular}{|c|c|c|c|c|c|c|c|c|}
\hline & \multicolumn{2}{|l|}{ Day 1} & \multicolumn{2}{|l|}{ Day 2} & \multicolumn{2}{|l|}{ Day 3} & \multicolumn{2}{|l|}{ Day 4} \\
\hline & a.m. & p.m. & a.m. & p.m. & a.m. & p.m. & 09.00-10.55 h staggered & $1 \mathrm{~h}$ and $55 \mathrm{~min}$ later staggered $10.55-13.00 \mathrm{~h}$ \\
\hline 1 & Sal & Sal & Sal & Sal & Sal & Sal & Sal & Sal \\
\hline 2 & $\mathrm{M} 10 \mathrm{mg} / \mathrm{kg}$ & $\mathrm{M} 10 \mathrm{mg} / \mathrm{kg}$ & $\mathrm{M} 20 \mathrm{mg} / \mathrm{kg}$ & $\mathrm{M} 20 \mathrm{mg} / \mathrm{kg}$ & $\mathrm{M} 40 \mathrm{mg} / \mathrm{kg}$ & $\mathrm{M} 40 \mathrm{mg} / \mathrm{kg}$ & M $20 \mathrm{mg} / \mathrm{kg}$ & Sal \\
\hline 3 & $\mathrm{M} 10 \mathrm{mg} / \mathrm{kg}$ & $\mathrm{M} 10 \mathrm{mg} / \mathrm{kg}$ & M $20 \mathrm{mg} / \mathrm{kg}$ & $\mathrm{M} 20 \mathrm{mg} / \mathrm{kg}$ & $\mathrm{M} 40 \mathrm{mg} / \mathrm{kg}$ & $\mathrm{M} 40 \mathrm{mg} / \mathrm{kg}$ & $\mathrm{M} 20 \mathrm{mg} / \mathrm{kg}$ & $\mathrm{N} 0.1 \mathrm{mg} / \mathrm{kg}$ \\
\hline 4 & $\mathrm{M} 10 \mathrm{mg} / \mathrm{kg}$ & $\mathrm{M} 10 \mathrm{mg} / \mathrm{kg}$ & M $20 \mathrm{mg} / \mathrm{kg}$ & $\mathrm{M} 20 \mathrm{mg} / \mathrm{kg}$ & $\mathrm{M} 40 \mathrm{mg} / \mathrm{kg}$ & $\mathrm{M} 40 \mathrm{mg} / \mathrm{kg}$ & $\mathrm{M} 20 \mathrm{mg} / \mathrm{kg}$ & $\mathrm{N} 0.2 \mathrm{mg} / \mathrm{kg}$ \\
\hline
\end{tabular}

Groups: 1: control mice, 2 : mice treated with morphine, 3 : morphine withdrawal mice $(0.1 \mathrm{mg} / \mathrm{kg}$ naloxone), 4 : morphine withdrawal mice (0.2 mg/kg naloxone).

M: morphine, N: naloxone, Sal: saline.

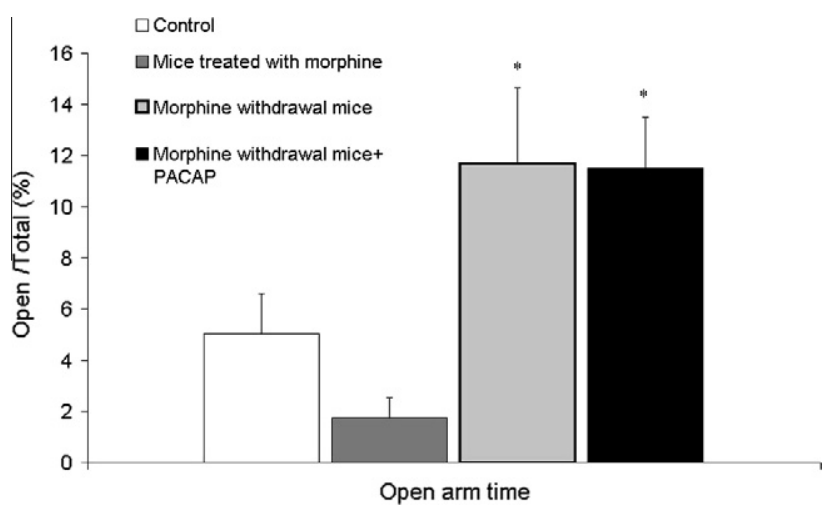

Fig. 4. The effect of naloxone on EPM behavior in mice treated with morphine in the presence of PACAP. Morphine and naloxone treatments were the same as outlined with Fig. 3. Mice were also treated once a day with either PACAP (500 ng/ $2 \mu \mathrm{l}$ ) or aCSF i.c.v. $30 \mathrm{~min}$ after morphine injection for 3 days. On day 4, PACAP or aCSF administrated $30 \mathrm{~min}$ prior to test. Accordingly, we injected morphine or saline $2 \mathrm{~h}$; PACAP or aCSF $30 \mathrm{~min}$; naloxone or saline $5 \mathrm{~min}$ prior to EPM test. Number of mice: control: 9 , mice treated with morphine: 10 , morphine withdrawal mice: 10, morphine withdrawal mice + PACAP: 8. Bars represent the open-arm time/total time rate, vertical lines on the top of the bars denote S.E.M., ${ }^{*} p<0.05$ vs. control mice and mice treated with morphine.

the mice treated with morphine. Moreover, naloxone significantly increased the number of open arm entries/total entries rate compared with control mice and mice received $0.1 \mathrm{mg} / \mathrm{kg}$ naloxone (Fig. 3). The $0.4 \mathrm{mg} / \mathrm{kg}$ dose of naloxone also increased the

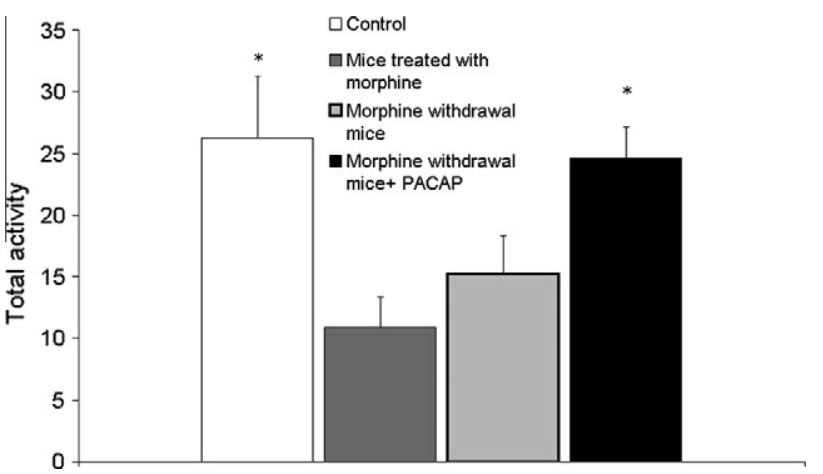

Fig. 5. The effects of PACAP on motor activity in controls and mice treated with morphine challenged with naloxone. Treatment protocol and the number of mice were the same as outlined with Fig. 4 . Bars represent the total activity, vertical lines on the top of the bars denote S.E.M., ${ }^{*} p<0.05$ compared with mice treated with morphine. PACAP significantly increased the total activity vs. mice treated with morphine. ${ }^{*} p<0.05$.

open-arm time/total time rate, but mice fell off from the open arm on every occasion (data not shown). There are no naloxonetreated control groups in this study; because previous studies proved that naloxone alone did not alter the behavior of mice on the plus-maze apparatus (Hodgson et al., 2008; Ribeiro and De Lima, 1998). In line with the literature, previous experiments done by our research group also demonstrated that naloxone alone had no effect on withdrawal jumping (Babarczy et al., 1996). We 
Table 3

Treatment schedule to study the effect of naloxone on EPM behavior in mice treated with morphine in the presence of PACAP.

\begin{tabular}{|c|c|c|c|c|c|c|c|c|c|}
\hline & \multicolumn{2}{|l|}{ Day 1} & \multicolumn{2}{|l|}{ Day 2} & \multicolumn{2}{|l|}{ Day 3} & \multicolumn{3}{|l|}{ Day 4} \\
\hline & a.m. & p.m. & a.m. & p.m. & a.m. & p.m. & $\begin{array}{l}09.00-10.55 \mathrm{~h} \\
\text { staggered }\end{array}$ & $\begin{array}{l}1 \mathrm{~h} 30 \mathrm{~min} \text { later staggered } \\
10.30-12.30 \mathrm{~h}\end{array}$ & $\begin{array}{l}1 \mathrm{~h} \text { and } 55 \mathrm{~min} \text { later } \\
\text { staggered } 10.55-13.00 \mathrm{~h}\end{array}$ \\
\hline 1 & Sal $+\mathrm{aCSF}$ & Sal & $\mathrm{Sal}+\mathrm{aCSF}$ & Sal & $\mathrm{Sal}+\mathrm{aCSF}$ & Sal & Sal & $\mathrm{aCSF}$ & Sal \\
\hline 2 & $\begin{array}{l}\mathrm{M} 10 \mathrm{mg} / \mathrm{kg} \\
\text { and } \mathrm{aCSF}\end{array}$ & $\begin{array}{l}\mathrm{M} \\
10 \mathrm{mg} / \\
\mathrm{kg}\end{array}$ & $\begin{array}{l}\mathrm{M} 20 \mathrm{mg} / \mathrm{kg} \\
\text { and } \mathrm{aCSF}\end{array}$ & $\begin{array}{l}\mathrm{M} \\
20 \mathrm{mg} / \\
\mathrm{kg}\end{array}$ & $\begin{array}{l}\mathrm{M} 40 \mathrm{mg} / \mathrm{kg} \\
\text { and } \mathrm{aCSF}\end{array}$ & $\begin{array}{l}\mathrm{M} \\
40 \mathrm{mg} / \\
\mathrm{kg}\end{array}$ & $\mathrm{M} 20 \mathrm{mg} / \mathrm{kg}$ & $\mathrm{aCSF}$ & Sal \\
\hline 3 & $\begin{array}{l}\mathrm{M} 10 \mathrm{mg} / \mathrm{kg} \\
\text { and } \mathrm{aCSF}\end{array}$ & $\begin{array}{l}\mathrm{M} \\
10 \mathrm{mg} / \\
\mathrm{kg}\end{array}$ & $\begin{array}{l}\mathrm{M} 20 \mathrm{mg} / \mathrm{kg} \\
\text { and } \mathrm{aCSF}\end{array}$ & $\begin{array}{l}\mathrm{M} \\
20 \mathrm{mg} / \\
\mathrm{kg}\end{array}$ & $\begin{array}{l}\mathrm{M} 40 \mathrm{mg} / \mathrm{kg} \\
\text { and } \mathrm{aCSF}\end{array}$ & $\begin{array}{l}\mathrm{M} \\
40 \mathrm{mg} / \\
\mathrm{kg}\end{array}$ & M $20 \mathrm{mg} / \mathrm{kg}$ & $\mathrm{aCSF}$ & $\mathrm{N}: 0.2 \mathrm{mg} / \mathrm{kg}$ \\
\hline 4 & $\begin{array}{l}\mathrm{M} 10 \mathrm{mg} / \mathrm{kg} \\
\text { and PACAP }\end{array}$ & $\begin{array}{l}\mathrm{M} \\
10 \mathrm{mg} / \\
\mathrm{kg}\end{array}$ & $\begin{array}{l}\mathrm{M} 20 \mathrm{mg} / \mathrm{kg} \\
\text { and PACAP }\end{array}$ & $\begin{array}{l}\mathrm{M} \\
20 \mathrm{mg} / \\
\mathrm{kg}\end{array}$ & $\begin{array}{l}\mathrm{M} 40 \mathrm{mg} / \mathrm{kg} \\
\text { and PACAP }\end{array}$ & $\begin{array}{l}\mathrm{M} \\
40 \mathrm{mg} / \\
\mathrm{kg}\end{array}$ & M $20 \mathrm{mg} / \mathrm{kg}$ & PACAP & $\mathrm{N}: 0.2 \mathrm{mg} / \mathrm{kg}$ \\
\hline
\end{tabular}

Groups: 1: control mice, 2: mice treated with morphine, 3: morphine withdrawal mice, 4: morphine withdrawal mice receiving PACAP.

M: morphine, N: naloxone, Sal: saline, aCSF: artificial cerebrospinal fluid.

examined the effect of chronic PACAP administration on naloxoneinduced morphine withdrawal behavior using EPM. In other experiments, acute administration of PACAP at dose dependent manner influenced morphine-induced locomotion: at lower doses $(0.03$ and $0.3 \mu \mathrm{g})$ increased, at higher dose inhibited ( $1 \mu \mathrm{g})$ morphine-induced locomotion (Marquez et al., 2009). According to another study, single i.c.v. doses of $500 \mathrm{ng}$ and $1 \mu \mathrm{g}$ PACAP had locomotor stimulating effect in open field test, 30 min post-treatment in rat (Adamik and Telegdy, 2004). Therefore, in our experiments 30 min after last PACAP injection ( $500 \mathrm{ng}$ ) the EPM test was started. After naloxone-precipitated withdrawal, mice treated with PACAP and morphine showed a significant increase in the total motor activity compared to the mice treated with morphine. Control mice exhibited similar behavior (Fig. 5). This increased total activity may be regarded as escape or defensive behavior or decrease feeling of fear (Hodgson et al., 2008). This phenomenon is perhaps mediated by dopamine receptors in the amygdala (Rezayof et al., 2009; Zhang and Schulteis, 2008), However, the role of dorsal periaqueductal gray and inferior colliculus cannot be ruled out (Avila et al., 2008; De et al., 2009). A recent study suggest that chronic stress (footshock, forced swim, oscillation stress, etc.) increases PACAP mRNA expression in the bed nucleus of the stria terminalis and PACAP is anxiogenic (Hammack et al., 2009). We could not confirm these results; PACAP alone increased the open arm time/ total time rate and had no effect on total activity. Though the higher dose of PACAP has shown to be more effective than the lower (500 ng) dose, its combination with chronically administered morphine caused a marked increase in mortality of mice. Chronic PACAP treatment did not influence significantly the open arm time/ total time rate in mice undergoing naloxone-precipitated morphine withdrawal. These results allude to anxiolytic effect of PACAP, but differences were not significant compared to aCSF treated control mice $(P<0.0614)$.

Jump latency is an accepted method to report the somatic signs of withdrawal (Babarczy et al., 1995a,b; Babarczy et al., 1996; Miller et al., 1983). Mice chronically treated with PACAP and morphine jumped off the platform earlier than mice treated with morphine after withdrawal. Thus, PACAP enhanced this aversive effect of opioid withdrawal (Fig. 1). A previous study carried out in our laboratory showed a similar result using morphine pellet implantation (Mácsai et al., 2002). Although withdrawal jumping is a somatic withdrawal symptom in mice and rats, perhaps this is the same escape behavior, which we experienced on EPM tests.

In conclusion, our study demonstrated that PACAP could modify several effect of morphine withdrawal in mice (e.g. total motor activity), but enhanced other negative effects (e.g. latency to jump). Based upon these experiments, it is difficult to determine whether PACAP exerted its effect on the expression or on the acquisition of morphine withdrawal. Earlier data showed that PACAP played an important role in thermoregulation and enhanced the chronic analgesic tolerance to morphine. Our data suggest that naloxone-precipitated withdrawal did not evoke anxiety-like behavior; rather, it induced anxiolytic effect in mice. PACAP was able to lower total activity on EPM upon chronic morphine challenge. These data may also help us to better understand the mechanisms of morphine withdrawal-induced behavioral changes and the physiological and pathological role of PACAP in different behavior responses.

\section{Conflict of interest statement}

The authors have no conflicts of interest to declare.

\section{Acknowledgments}

The authors wish to gratefully acknowledge the technical assistance of Gusztáv Kiss, Âgnes Pál and Ildikó Sípos. This study was supported by ETT-Grant (355-08/2009) and TÁMOP 4.2.1./B-09/ KONV-2010-0005.

\section{References}

Absood, A., Chen, D., Hakanson, R., 1992. Neuropeptides of the vasoactive intestinal peptide/helodermin/pituitary adenylate cyclase activating peptide family elevate plasma cAMP in mice: comparison with a range of other regulatory peptides. Regulatory Peptides 40, 311-322.

Adamik, A., Telegdy, G., 2004. Involvement of different receptors in pituitary adenylate cyclase activating polypeptide induced open field activity in rats. Neuropeptides 38, 16-20.

Arimura, A., 1992. Pituitary adenylate cyclase activating polypeptide (PACAP): discovery and current status of research. Regulatory Peptides 37, 287-303.

Avila, M.A., Ruggiero, R.N., Cabral, A., Brandao, M.L., Nobre, M.J., Castilho, V.M., 2008. Involvement of the midbrain tectum in the unconditioned fear promoted by morphine withdrawal. European Journal of Pharmacology 590, 217-223.

Azarov, A.V., Szabó, G., Telegdy, G., 1992. Effects of atrial natriuretic peptide on acute and chronic effects of morphine. Pharmacology Biochemistry and Behavior 43, 193-197.

Babarczy, E., Szabó, G., Telegdy, G., 1995a. Effects of secretin on acute and chronic effects of morphine. Pharmacology Biochemistry and Behavior 51, 469-472.

Babarczy, E., Vizi, Z., Tóth, G., Telegdy, G., 1995b. C-type natriuretic peptide can modify the acute and chronic effects of morphine. Neuropeptides 29, 145-149.

Babarczy, E., Vizi, Z., Szabó, G., Telegdy, G., 1996. Effects of brain natriuretic peptide on effects of morphine in mice. Neuropeptides 30, 438-442.

Beitner, D.B., Duman, R.S., Nestler, E.J., 1989. A novel action of morphine in the rat locus coeruleus: persistent decrease in adenylate cyclase. Molecular Pharmacology 35, 559-564.

Bie, B., Peng, Y., Zhang, Y., Pan, Z.Z., 2005. CAMP-mediated mechanisms for pain sensitization during opioid withdrawal. Journal of Neuroscience 25, 3824-3832.

Buckman, S.G., Hodgson, S.R., Hofford, R.S., Eitan, S., 2009. Increased elevated plus maze open-arm time in mice during spontaneous morphine withdrawal. Behavioral Brain Research 197, 454-456. 
Budziszewska, B., Jaworska-Feil, L., Lason, W., 1996. Neurosteroids and the naloxone-precipitated withdrawal syndrome in morphine-dependent mice. European Neuropsychopharmacology 6, 135-140.

Cauvin, A., Buscail, L., Gourlet, P., De, N.P., Gossen, D., Arimura, A., Miyata, A., Coy, D.H., Robberecht, P., Christophe, J., 1990. The novel VIP-like hypothalamic polypeptide PACAP interacts with high affinity receptors in the human neuroblastoma cell line NB-OK. Peptides 11, 773-777.

Christophe, J., 1993. Type I receptors for PACAP (a neuropeptide even more important than VIP?). Biochimica et Biophysica Acta 1154, 183-199.

Contet, C., Filliol, D., Matifas, A., Kieffer, B.L., 2008. Morphine-induced analgesic tolerance, locomotor sensitization and physical dependence do not require modification of mu opioid receptor, cdk5 and adenylate cyclase activity. Neuropharmacology 54, 475-486.

De, R.J., Avila, M.A., Ruggiero, R.N., Nobre, M.J., Brandao, M.L., Castilho, V.M., 2009 The unconditioned fear produced by morphine withdrawal is regulated by muand kappa-opioid receptors in the midbrain tectum. Behavioral Brain Research 204, 140-146.

Dietl, M.M., Hof, P.R., Martin, J.L., Magistretti, P.J., Palacios, J.M., 1990. Autoradiographic analysis of the distribution of vasoactive intestinal peptide binding sites in the vertebrate central nervous system: a phylogenetic study. Brain Research 520, 14-26.

Gourlet, P., Vandermeers, A., Vandermeers-Piret, M.C., De, N.P., Waelbroeck, M. Robberecht, P., 1996. Effect of introduction of an arginine16 in VIP, PACAP and secretin on ligand affinity for the receptors. Biochimica et Biophysica Acta 1314, 267-273.

Gourlet, P., Vandermeers, A., Van, R.J., De, N.P., Cnudde, J., Waelbroeck, M. Robberecht, P., 1998. Analogues of VIP, helodermin, and PACAP discriminate between rat and human VIP1 and VIP2 receptors. Annals of the New York Academy of Sciences 865, 247-252.

Hammack, S.E., Cheung, J., Rhodes, K.M., Schutz, K.C., Falls, W.A., Braas, K.M., May, V., 2009. Chronic stress increases pituitary adenylate cyclase-activating peptide (PACAP) and brain-derived neurotrophic factor (BDNF) mRNA expression in the bed nucleus of the stria terminalis (BNST): roles for PACAP in anxiety-like behavior. Psychoneuroendocrinology 34, 833-843.

Higgins, G.A., Sellers, E.M., 1994. Antagonist-precipitated opioid withdrawal in rats: evidence for dissociations between physical and motivational signs. Pharmacology Biochemistry and Behavior 48, 1-8.

Hodgson, S.R., Hofford, R.S., Norris, C.J., Eitan, S., 2008. Increased elevated plus maze open-arm time in mice during naloxone-precipitated morphine withdrawal Behavioural Pharmacology 19, 805-811.

Joo, K.M., Chung, Y.H., Kim, M.K., Nam, R.H., Lee, B.L., Lee, K.H., Cha, C.I., 2004 Distribution of vasoactive intestinal peptide and pituitary adenylate cyclaseactivating polypeptide receptors (VPAC1, VPAC2, and PAC1 receptor) in the rat brain. Journal of Comparative Neurology 476, 388-413.

Kishioka, S., Nishida, S., Fukunaga, Y., Yamamoto, H., 1994. Quantitative properties of plasma corticosterone elevation induced by naloxone-precipitated withdrawal in morphine-dependent rats. Japanese Journal of Pharmacology $66,257-263$.

Kuriyama, K., Nakagawa, K., Naito, K., Muramatsu, M., 1978. Morphine-induced changes in cyclic AMP metabolism and protein kinase activity in the brain Japanese Journal of Pharmacology 28, 73-84.

Lister, R.G., 1987. The use of a plus-maze to measure anxiety in the mouse. Psychopharmacology (Berl) 92, 180-185.

Mácsai, M., Pataki, I., Tóth, G., Szabó, G., 2002. The effects of pituitary adenylate cyclase-activating polypeptide on acute and chronic morphine actions in mice. Regulatory Peptides 109, 57-62.
Marquez, P., Bebawy, D., Lelievre, V., Coute, A.C., Evans, C.J., Waschek, J.A., Lutfy, K., 2009. The role of endogenous PACAP in motor stimulation and conditioned place preference induced by morphine in mice. Psychopharmacology (Berl) 204, 457-463.

Miller, J.M., Poulsen-Burke, J., Cochin, J., 1983. Latency to first naloxone-induced jump as a measure of precipitated abstinence intensity in morphine-dependent mice and the interaction of set on this test. Life Sciences 32, 2205-2213.

Miyata, A., Jiang, L., Dahl, R.D., Kitada, C., Kubo, K., Fujino, M., Minamino, N., Arimura, A., 1990. Isolation of a neuropeptide corresponding to the N-terminal 27 residues of the pituitary adenylate cyclase activating polypeptide with 38 residues (PACAP38). Biochemical and Biophysical Research Communications $170,643-648$.

Pataki, I., Adamik, A., Jászberényi, M., Mácsai, M., Telegdy, G., 2000. Pituitary adenylate cyclase-activating polypeptide induces hyperthermia in the rat. Neuropharmacology 39, 1303-1308.

Pataki, I., Adamik, A., Jászberényi, M., Mácsai, M., Telegdy, G., 2003. Involvement of transmitters in pituitary adenylate cyclase-activating polypeptide-induced hyperthermia. Regulatory Peptides 115, 187-193.

Rabbani, M., Hajhashemi, V., Mesripour, A., 2009. Increase in brain corticosterone concentration and recognition memory impairment following morphine withdrawal in mice. Stress 12, 451-456.

Rezayof, A., Hosseini, S.S., Zarrindast, M.R., 2009. Effects of morphine on rat behaviour in the elevated plus maze: the role of central amygdala dopamine receptors. Behavioral Brain Research 202, 171-178.

Ribeiro, S.J., De Lima, T.C., 1998. Naloxone-induced changes in tachykinin NK3 receptor modulation of experimental anxiety in mice. Neuroscience Letters 258, 155-158.

Sándor, K., Kormos, V., Botz, B., Imreh, A., Bölcskei, K., Gaszner, B., Markovics, A., Szolcsányi, J., Shintani, N., Hashimoto, H., Baba, A., Reglődi, D., Helyes, Z., 2010. Impaired nocifensive behaviours and mechanical hyperalgesia, but enhanced thermal allodynia in pituitary adenylate cyclase-activating polypeptide deficient mice. Neuropeptides 44, 363-371.

Schulteis, G., Markou, A., Gold, L.H., Stinus, L., Koob, G.F., 1994. Relative sensitivity to naloxone of multiple indices of opiate withdrawal: a quantitative doseresponse analysis. Journal of Pharmacology and Experimental Therapeutics 271, 1391-1398.

Schulteis, G., Yackey, M., Risbrough, V., Koob, G.F., 1998. Anxiogenic-like effects of spontaneous and naloxone-precipitated opiate withdrawal in the elevated plusmaze. Pharmacology Biochemistry and Behavior 60, 727-731.

Szakács, J., Mácsai, M., Dochnal, R., Babits, A., Pál, A., Szabó, G., 2010. The effect of the neuropeptide PACAP on morphine-induced locomotor activity. Acta Physiologica Hungarica 97, 475.

Wang, Y.Q., Guo, J., Wang, S.B., Fang, Q., He, F., Wang, R., 2008. Neuropeptide FF receptors antagonist, RF9, attenuates opioid-evoked hypothermia in mice. Peptides 29, 1183-1190.

Xiao, D., Chu, M.S., Lee, K.Y., Wong, A.O., Lin, H.R., 2002. Effects of pituitary adenylate cyclase activating polypeptide (PACAP) on intracellular cAMP and $\mathrm{Ca}\left(2^{+}\right)$levels in common carp (Cyprinus carpio) pituitary cells in vitro. Sheng $\mathrm{Wu}$ Hua Xue.Yu Sheng Wu Wu Li Xue.Bao. (Shanghai) 34, 790-795.

Zhang, Z., Schulteis, G., 2008. Withdrawal from acute morphine dependence is accompanied by increased anxiety-like behavior in the elevated plus maze. Pharmacology Biochemistry and Behavior 89, 392-403.

Zhou, C.J., Yada, T., Kohno, D., Kikuyama, S., Suzuki, R., Mizushima, H., Shioda, S., 2001. PACAP activates PKA, PKC and $\mathrm{Ca}(2+)$ signaling cascades in rat neuroepithelial cells. Peptides 22, 1111-1117. 